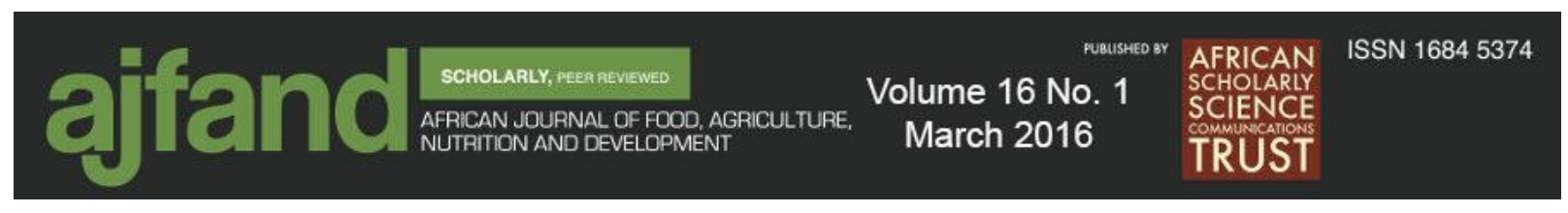

DOI: $10.18697 /$ ajfand.73.14095

\title{
ASSESSING THE DETERMINANTS OF TISSUE CULTURE BANANA ADOPTION IN WESTERN KENYA
}

\author{
Wanyama JM1,2*, Obare GA, Owuor $\mathbf{G}^{2}$ and $L$ Wasilwa ${ }^{3}$
}

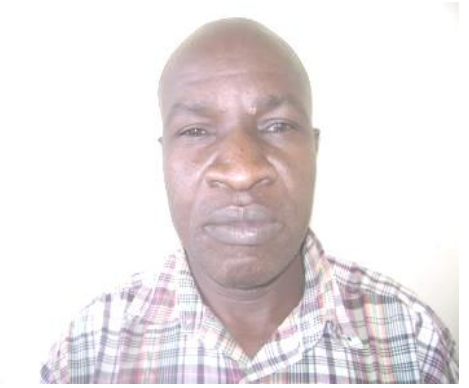

Japhether M Wanyama

*Corresponding author email: jmasindektl@yahoo.com. OR Japheth.wanyama@kalro.org.

${ }^{1}$ Department of Agricultural Economics and Agribusiness Management, Egerton University, Kenya. P. O. Box 536-40115, Njoro, Kenya

${ }^{2}$ Kenya Agricultural and Livestock Research Organization (KALRO), FCRI. Headquarters, P. O. Box 450-30200, Kitale, Kenya

${ }^{3}$ Crop Systems Unit, Kenya Agricultural and Livestock Research Organization (KALRO), Headquarters, P. O. Box 87511, Nairobi, Kenya 


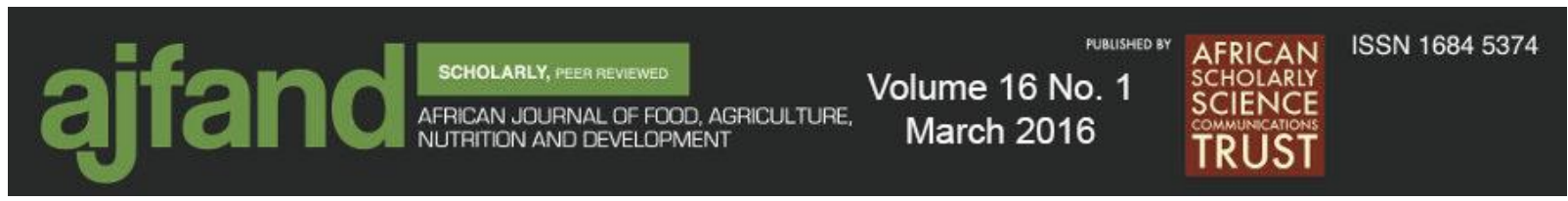

\begin{abstract}
In this study cross-section data was used to analyze the effect of farmers' demographic, socioeconomic and institutional setting, market access and physical attributes on the probability and intensity of tissue culture banana (TCB) adoption. The study was carried out between July 2011 and November 2011. Both descriptive (mean, variance, promotions) and regression analysis were used in the analysis. A double hurdle regression model was fitted on the data. Using multistage sampling technique, four counties and eight sublocations were randomly selected. Using random sampling technique, three hundred and thirty farmers were selected from a list of banana households in the selected sub-locations. The adoption level of tissue culture banana (TCB) was about $32 \%$. The results also revealed that the likelihood of TCB adoption was significantly influenced by: availability of TCB planting material, proportion of banana income to the total farm income, per capita household expenditure and the location of the farmer in Kisii County; while those that significantly influenced the intensity of TCB adoption were: occupation of farmers, family size, labour source, farm size, soil fertility, availability/access of TCB plantlets to farmers, distance to banana market, use of manure in planting banana, access to agricultural extension services and index of TCB/non-TCB banana cultivar attributes which were scored by farmers. Compared to West Pokot County, farmers located in Bungoma County are more significantly and likely to adopt TCB technology. Therefore, the results of the study suggest that the probability of adoption and intensity of the use of TCB should be enhanced. This can be done by taking cognizance of these variables in order to meet the priority needs of the smallholder farmers who were the target group. This would lead to alleviating banana shortage in the region for enhanced food security. Subsequently, actors along the banana value chain are encouraged to target the intervention strategies based on the identified farmer, farm and institutional characteristics for enhanced impact on food provision. Opening up more TCB multiplication centres in different regions will make farmers access the TCB technology for enhanced impact on the target population.
\end{abstract}

Key words: Farmer, Adoption, Tissue culture banana, double-hurdle, model, West Kenya 


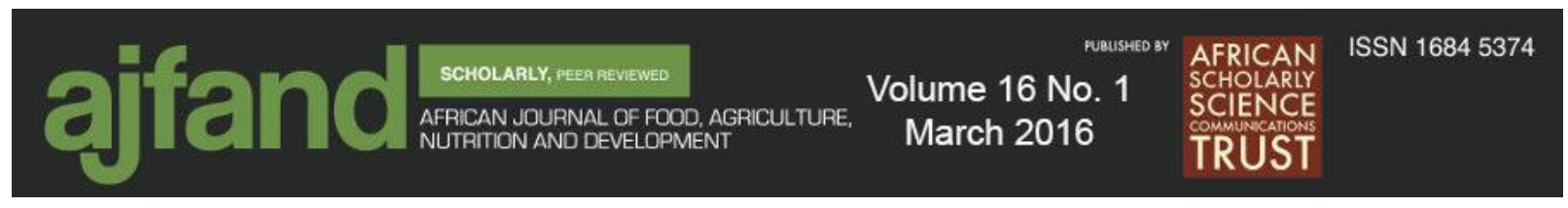

\section{INTRODUCTION}

Increasing agricultural production and post-harvest management and disposal is a priority option for reducing the ever increasing food insecurity and poverty not only in Kenya but also in other sub-Saharan African countries. It is estimated that about $80 \%$ of people in Kenya live and work in rural areas, and nearly $90 \%$ of the population within rural areas is inherently linked to agriculture as a main livelihood strategy [1,2]. Therefore, agriculture is perceived as a vehicle for economic growth at both household and national levels. One of the challenges in agriculture is the progressively declining farm sizes, not only among the predominantly large-scale farming systems, but also in the pre-dominantly smallholder zones of Kenya [3]. Farm lands are being converted to residential plots, roads and other non-farming activities [4]. This challenge demands innovativeness among farmers and other actors in upgrading agricultural product value chains, targeting not only yieldincreasing but also value-adding technologies.

Efforts have been spent on up-grading banana production through the development and dissemination of technologies. One such technology is the tissue culture banana (TCB). This study is not only concerned with assessing the likelihood of TCB, but also with the intensity of adoption. It is recognized that Agricultural Technology (like TCB) adoption has multiple benefits to the target communities [5]. The technologies were perceived to raise farm productivity through rapid multiplication of TCB plantlets and distributing them to farmers [6]. Subsequently, the increased banana production would improve household incomes, enhance food security, increasing employment through rapid multiplication of TCB plantlets and distributing them to farmers [6]. However, the question is 'what are the factors influencing the adoption of the TCB given that the technology has not been fully adopted among the target groups since 1998?' The technology has also been modified through the use of suckers. It has been documented that agricultural innovations that seemed promising have been met with partial success, as measured by empirical analyses on their rates of adoption [7, 8]. Limited access to credit, inadequate farm size, risk aversion, inconsistent supply of production inputs like TCB plantlets and household labour mobility have all been shown to inhibit farmer household investment in agricultural innovations [9].

Some studies have summarised the critical household characteristics influencing technology adoption in the developing countries [10-16]. These studies have demonstrated that these characteristics can be grouped into four primary classes, namely: physical and natural characteristics, human assets, social assets, and financial assets. The physical and natural characteristics constitute area of land under cultivation, acreage, pre-adoption income/wealth and access to water all year round. Human assets include quality and quantity of household labor, the age of head of household and years of education of head of household were proxies for the quality of labour and household size and the dependency ratio were proxies for quantity of labor. Social assets included farmers' membership in groups and the number of extension visits. Financial assets were; farmer access to formal or informal credit, capital assets and the quality and ownership status of the home [9]. This 


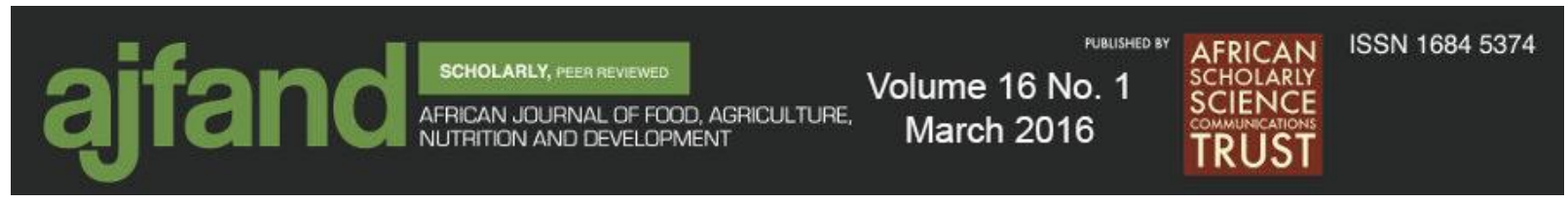

research sought to explicitly model the probability and intensity of TCB adoption in selected parts of west Kenya using these factors.

\section{METHODOLOGY}

\section{The Study Area}

The study was conducted in four counties of western Kenya: Trans Nzoia, West Pokot, Bungoma and Kisii (Figure 1). Kisii and Bungoma were among the counties where TCB was introduced while Trans Nzoia and West Pokot were late entrants. The acreage under banana is increasing over years. Trans Nzoia County is the main maize producing and exporting region in Kenya. The county is located at latitude $0^{\circ} 52^{\prime}-1^{\circ} 18^{\prime} \mathrm{S}$, and longitude $34^{\circ} 38^{\prime}-35^{\circ} 23^{\prime} \mathrm{E}$ with human population of about 818,757 and a density of 741 persons per square kilometer $[17,18]$. Bungoma County lies between latitude $0^{0} 25.3^{\prime}$ and $0^{0} 53.2^{\prime}$ North and longitude $34^{0} 21.4^{\prime}$ and $35^{\circ} 04^{\prime}$ East. The county population was estimated at 1.6 million in $2009[19,20]$. The population density is evenly distributed with an average population density of 482 persons per square $\mathrm{km}$. It covers an area of 2,068 $\mathrm{km}^{2}$. The area is popularly known for its maize, wheat, tea, sugarcane, dairy and banana production. West Pokot County lies between Latitudes $1^{\circ} 10^{\prime}$ and $30^{\circ} 40^{\prime} \mathrm{N}$ and Longitudes $34^{\circ} 50^{\prime}$ and $35^{\circ}$ $50^{\prime} \mathrm{E}$ with a total area of 9,100 square $\mathrm{km}$ [21]. Some of the common food crops grown in the area are cassava, finger millet, sorghum, ground nuts and vegetables including banana whose acreage is increasing over years [18]. Kisii County lies between latitude 0 30' and 10 ' South and longitude $3438^{\prime}$ and 350 ' East. The county covers a total area of 1,332.7 square $\mathrm{km}$. The county's total population was projected at 1.2 million persons in 2012 [22]. The county receives adequate rainfall, coupled with moderate temperature and is suitable for growing of crops like tea, coffee, maize, beans, finger millet, potatoes, bananas and groundnuts. This also makes it possible to practice dairy farming. 

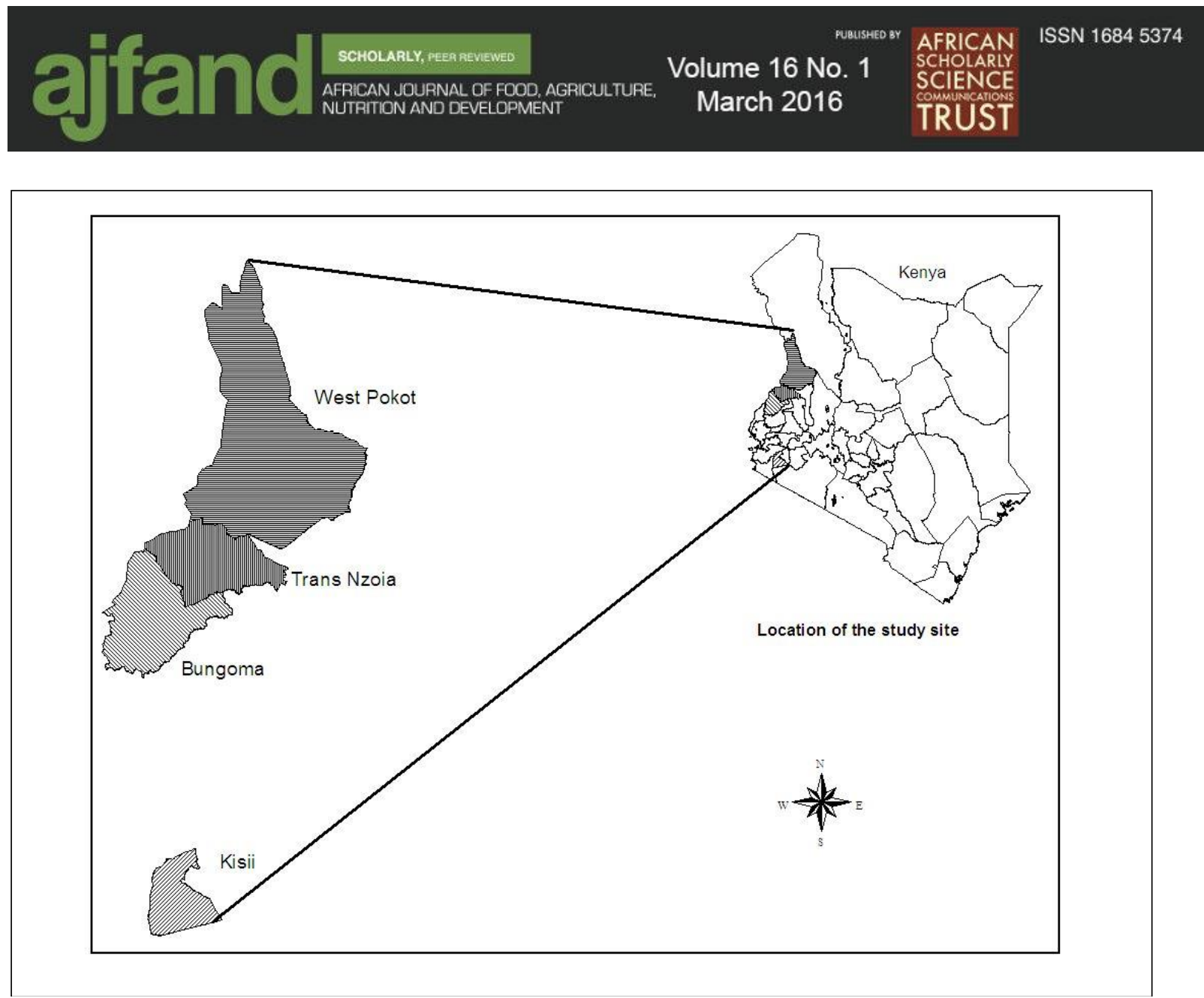

Figure 1: Map of Kenya showing the 4 survey sites/counties

\section{Sampling technique}

The target population for this study was made up of banana growing farmers in Western Kenya. These included TCB and non-TCB adopters in the selected counties. Multistage random sampling technique was adapted. First, four counties were purposively selected from 47 counties. Two districts were randomly selected from each county. Five sub locations were randomly selected from each of the districts, thus giving a total of twelve villages. Lastly, 331 farmers were randomly selected from each of the 12 villages using simple random sampling technique after listing all banana farmers in the sub location. This was facilitated by the front-line agricultural extension officers of the Ministry of Agriculture Livestock Development and Fisheries.

\section{Analytical techniques}

In modeling the utility or satisfaction derived from the use/adoption of TCB, the economic values or benefits associated with non-TCB cultivars such as bogoya and bokoboko, as well as the TCB were considered. A typical household seeks to maximize a multi-dimensional objective function, including food insecurity reduction and increasing incomes resource constraints. When there is a change in economic parameters associated to TCB technology use, the central question is related to how much benefits are received by the decision maker or household. Thus, the change in benefits (production and productivity of banana) associated with this adoption was used as the basis for economic valuation process. When 


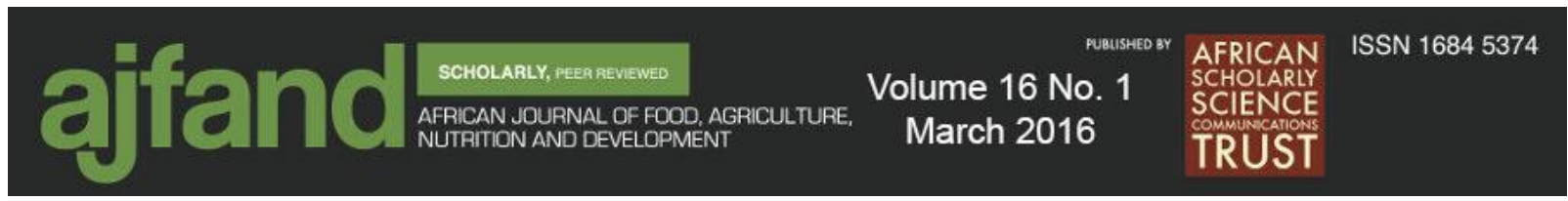

a farmer faces a change in a measurable attribute, for example higher benefits from TCB cultivars $(Q)$, then $Q$ changes from $Q_{0}$ to $Q_{1}$ (with $Q_{1}>Q_{0}$ ). The indirect utility function $U$ after the change becomes higher than the status quo. Now the status quo can be functionally represented as:

$$
\begin{array}{ll}
U_{T C B}=U_{T C B}\left(Z_{i}, Y_{i}, T_{i}, \varepsilon_{i}\right) & 1 \\
U_{N o n_{-} T C B}=U_{N o n T C B}\left(Z_{i}, Y_{i}, T_{i}, \varepsilon_{i}\right) & 2 \\
U_{\text {Net }}=U_{T C B}-U_{\text {Non_TCB }}>0 & 3
\end{array}
$$

Subject to resource (land, labour, capital and technical knowhow) constraints where, $U_{N e t}$, refers to the farmer's net utility associated with adoption of TCB, $U_{T C B}$ utility associated with adoption of TCB, $U_{N o n_{-} T C B}$ utility associated with adoption of non-TCB, $Z_{j}$ is a vector of the farmer's socio-economic variables, $Y_{i}$ is bio-physical factors and $T_{i}$ are TCB technology attributes, and $\varepsilon_{i}$ is the model stochastic error term. The farmers would opt to adopt TCB technology if and only if the following condition holds:

$U_{T C B}\left(Z_{i}, Y_{i}, T_{i}, \varepsilon_{i}\right)>U_{N o n T C B}\left(Z_{i}, Y_{i}, T_{i}, \varepsilon_{i}\right)$

This means that the benefits associated with TCB adoption are greater than those associated with non-adoption.

\section{Empirical data analysis}

Both descriptive (mean, variance, promotions) and regression analysis were used in the analysis. The Double-hurdle model (DHM) in this study was used to determine the factors that influence the decision to adopt and the extent of adoption of TCB in order to identify factors influencing the up-scaling of the technology. The underlying assumption in the DHM approach is that farmers make two decisions with regard to their decision to grow TCB and that these decisions are sequential. The first decision, hereby referred to as the first hurdle, is whether a farmer will grow TCB and the second decision is about the amount of land allocated, thus, the second hurdle, conditional on the first decision [23, 24]. The importance of treating the two decisions independently lies in the fact that factors that affect one's decision to adopt may be different from those that affect the decision on how much to adopt. Given that all farmers are potential adopters and beneficiaries of TCB, knowing their current circumstances then dictates their likelihood to adopt the TCB (the first hurdle) and the extent of adoption (the second hurdle) of number of TCB stools to grow. The advantage with this approach is that it allows us to understand characteristics of the class of households that would never adopt the TCB innovation. Thus, the probability of a household belonging to a particular group is subject to a set of household characteristics. Farmer $i$ 's adoption equation in growing of TCB can be expressed by Yimer [25] as:

$$
d_{i}^{*}=z_{i} \boldsymbol{\alpha}+v_{i} \text { with } d_{\mathrm{i}}=1 \text { for adoption or } 0 \text { otherwise }
$$




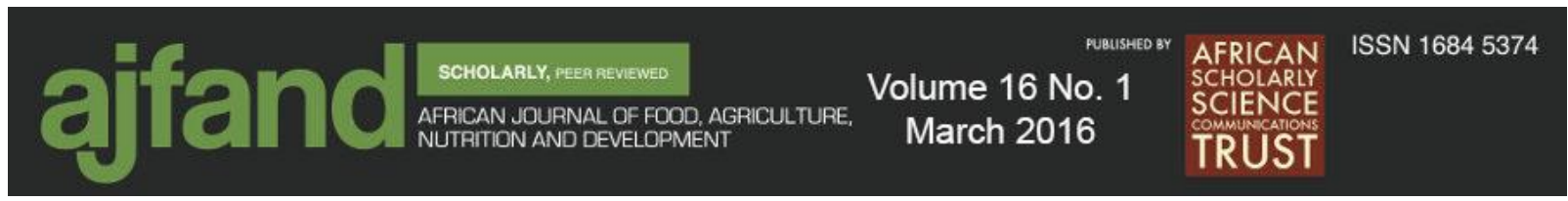

and her adoption intensity is given as:

$$
y_{i}^{*}=\boldsymbol{x}_{i} \boldsymbol{\beta}+u_{i}
$$

where $d_{i}^{*}$ in the logit equation is the latent variable describing the household's decision to adopt TCB, $y_{i}^{*}$ in the truncated Tobit equation is the intensity of TCB adoption, $z_{i}$ is a vector of variables explaining whether a household adopts TCB, $x_{i}$ is a vector of variables explaining how much land the household allocates to TCB, and $v_{i}$ and $u_{i}$ are the random error terms. Random errors $u_{i}$ and $v_{i}$ are normally distributed as $N(0,1)$ and $N(0$, 2

$\sigma$ ), respectively. It also is assumed that $u_{i}$ and $v_{i}$ are independent. Furthermore it is assumed that for each respondent, the decision on whether to adopt the TCB technology and the decision about the adoption level are made independently.

The factors that were posited to positively/negatively influence the likelihood and intensity of TCB are given in Table 1. Adoption of agricultural technologies including TCB, is influenced by a number of factors that can be broadly divided into four general categories, namely: socioeconomic factors (SE), Technology attributes (TA), Institutional factors (IF) and bio-physical/environmental factors (EF) [26-29]. Against this background several factors were identified to influence TCB as shown in Table 1. The estimation of the doublehurdle model requires specification of the error structure. After the specification adjustments, the log-likelihood function is written as follows [30, 31]:

$$
\log L=\sum_{0} \ln \left[1-\Phi \alpha z_{i}\left(\frac{\beta x_{i}}{\sigma}\right)\right]+\sum_{+} \ln \left[\Phi \alpha z_{i} \frac{1}{\sigma} \varphi\left(\frac{y_{i}-\beta x_{i}}{\sigma}\right)\right]
$$

in which ' 0 ' indicates summation over the zero observations in the sample, while "'+'" indicates summation over positive observation. The $\Phi$ and $\phi$ symbols are the probability density functions (PDF) and cumulative distribution function (CDF) for a standard normal random variable, respectively. $x_{i}$ is a vector of independent variables explaining the intensity of TCB and $\beta$ is the corresponding vector of parameters to be estimated [32]. In order to justify the use of the DHM, a restriction test was carried out where the log likelihood values were obtained from a separate estimation of Tobit, univariate logit and truncated regression models as illustrated by Greene [32]. Based on the values obtained, the following likelihood ratio statistic was computed using the formula given in equations 8 and 9:

$$
\begin{aligned}
& L L=-2\left(L L_{\text {Logit }}+L L_{\text {Truncatedregression }}-L L_{\text {Tobit }}\right) \approx \chi_{p}{ }^{2} \\
& L L=-2\left(L L_{D H M}-L L_{\text {Tobit }}\right) \approx \chi_{p}{ }^{2}
\end{aligned}
$$




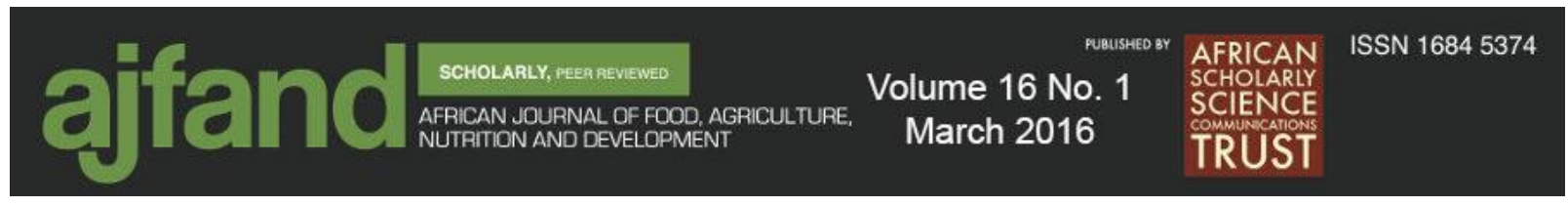

where LL logit $=$ likelihood for probit model; $L_{\text {truncatedregression }}=$ likelihood for truncated Tobit model; and $p$ is the number of independent variables in the equations. The Tobit model arises when $\lambda=\beta / \sigma$ and $x=z$. The test statistics is computed as given in equation 10 .

$\mathrm{H}_{0}: \lambda=\beta / \sigma$ and $-H_{a}: \lambda \neq \beta / \sigma$.

Thus, the test statistic has a chi-square $\left(\chi^{2}\right)$ distribution with degrees of freedom equal to the number of independent variables (including the intercept), ' $p$ '. The Tobit model is rejected in favour of the Double Hurdle model if $L L$ exceeds the appropriate chi-square critical value [33]. This index measured the technological attributes of TCB technology. The likert scale rating ranged from 1 to 4 (1=very poor; $2=$ Poor; $3=$ Good; $4=$ Excellent). The technological attributes that were considered included: disease-tolerance, pesttolerance, yield potential, sweetness, cookability, lodging, suckering ability, finger size, finger length, bunch size, feed for livestock, drought- tolerance, maturity period, ripening and storability. The index was computed by summing up the farmers' scores against each of the attributes.

\section{RESULTS}

\section{General socio-economic characteristics of respondents}

Shown in Table 2 are the general socio-economic characteristics of the respondents. The average household size for TCB practicing farmers was 6.9, while that of non-practicing was 7.2, with an overall mean of 7.0 members. The average age of those farmers who had adopted of TCB technology was 51.2 years, while that of non-adopters was 51.6 years with an overall mean age of 51.4. The distance to the banana selling markets was significantly different $(\mathrm{p} \leq 0.05)$. It was $38 \mathrm{~km}$ for those farmers who planted TCB, while for those who did not, it was $14.3 \mathrm{~km}$ with a pooled mean of $37.1 \mathrm{~km}$. The period of planting banana for TCB adopters was 17.5 years, while that for non-adopters was 13.8 years with an overall mean of 23 years. The average number of years of farmers in planting TCB banana was about seven years. The number of years in farming for head of household was 22.0 years for non-TCB adopters, while that for non-TCB adopters was 20.0 years. The overall mean of period in years of farming for respondents was 20.0 years. The average number of livestock for TCB adopters was 7.5, while that for non-adopters was 4.4. The average farm size was about 10.6 acres for TCB adopters, while that for non-adopters was 6.7 acres with an overall mean of about 8.8 acres. On the other hand, the average arable land for adopters was 8.7 acres, while that of non-adopters was 5.2 with an overall mean of 7.1 acres. The main occupation for adopters was $73.1 \%$ (farming) and $17.2 \%$ (off-farm), while for nonadopters was $72.2 \%$ (farming) and $12.7 \%$ (off-farm). The proportion of male headed respondents for adopters was $45 \%$, while for non-adopters was $37 \%$. Across all the groups majority of farmers had attained at least primary level of education. Most of the respondents ( $52 \%$ for adopters and $61 \%$ for non-adopters) had land title deeds. Most of the farmers perceived fertility level of farmers to be at least from medium to high $(89 \%$ for 


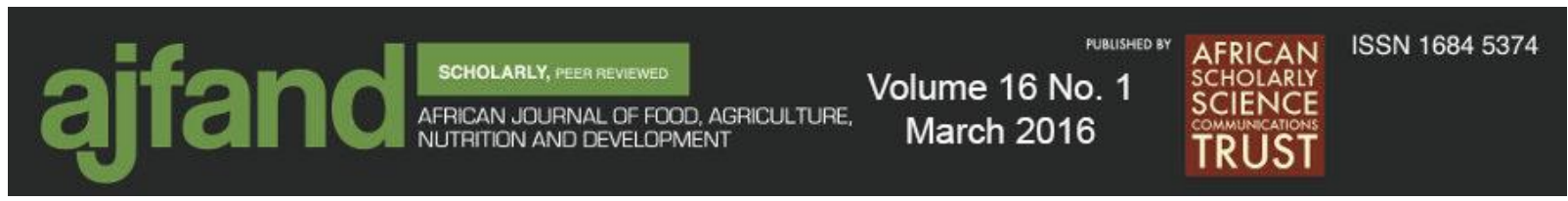

adopters and $98 \%$ for non-adopters). The proportion of households using family labour was about $84 \%$ for both groups and those using hired labour was higher in TCB practicing farmers (79\%) compared to those who were not planting TCB (66\%).

\section{DHM Model Results}

The first step of the analysis in estimating determinants of participation in TCB and their intensity of TCB adoption consisted of testing the Tobit model against the two-stage Cragg Tobit alternative model. Likelihood Ratio test was conducted to test the suitability of the double hurdle model against the Tobit model. Test statistics led to the Tobit model rejection in favour of the DHM because the computed lambda from the likelihood ratios exceeded the critical $\chi^{2}$ value. The significant Log likelihood Wald $\chi^{2}$ value of 126.86 indicated that the explanatory variables jointly influence the farmers' decision to adopt TCB technology. Table 3 shows the results of the DH model on household's participation in TCB. Tiers 1 and 2 are maximum likelihood coefficients of the determinants of probability of engagement in TCB and the intensity of TCB adoption, respectively.

\section{The logit Model Results (First hurdle)}

The logit model was proposed for the first stage of the double hurdle to predict farmers' likelihood of adopting TCB technology. The variables that were posited to influence likelihood of TCB adoption and were significant at $\mathrm{p}<0.01$ were: availability of TCB planting plantlet material (q8tcavl), proportion of banana income to the total farm income (lnbanprop), per capita household consumption expenditure (Lnpcdy) and the location of the farmer in Kisii County (kisidumy). Farmers' access to TCB plantlets positively and significantly $(\mathrm{p} \leq 0.01)$ influenced TCB adoption (Table 3). The planting material was available to farmers either through formal or informal distribution systems. The proportion of banana income to the total income significantly and positively influenced TCB adoption $(\mathrm{p} \leq 0.10)$. The probability of TCB adoption increases by $1.7 \%$ for every proportionate change in income from banana. The Kisii County location variable (kisidumy) was positive and significant at $\mathrm{p} \leq 0.10$. The probability of TCB adoption increases by $13.2 \%$ for every additional farmer located in Kisii County. In addition, per capita household consumption expenditure variable (lnpcdy) was positive and significant at $\mathrm{p} \leq 0.10$. The probability of TCB adoption increases by $2.1 \%$ for every one unit increase in per capita households' expenditure.

\section{The Truncated Tobit Model (Second hurdle)}

Out of the 20 variables posited to influence the intensity of TCB adoption, 11 were significant at $\mathrm{p} \leq 0.10$ (Table 3). The off-farm occupation of household head (ocup_off), was positive and significant $(\mathrm{p} \leq 0.01)$. A unit increase in the number of households with off-farm income leads to an increase of 2.0 units in TCB adoption intensity. The variable farming as main occupation of farmers (ocup_far), was positive and significant $(p \leq 0.05)$. Thus a unit increase in the number of people involved in farming leads to an increase of 1.6 units in TCB adoption intensity. 


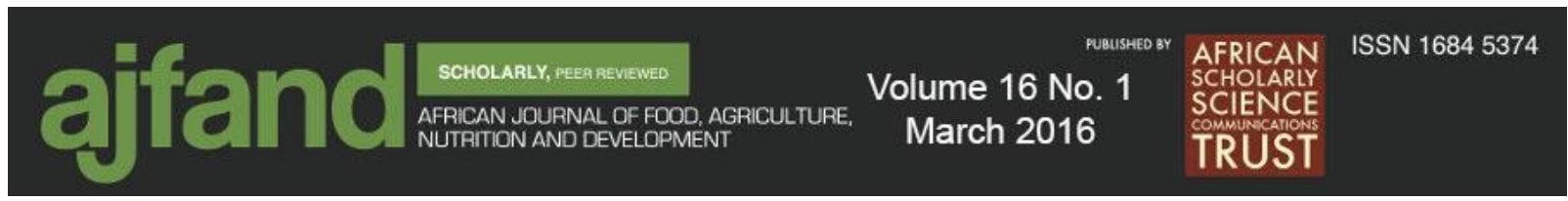

The use of family members as main labour source on the farm (q2labfam) was positive and significant, at $\mathrm{p} \leq 0.01$ with a unit increase in the number of household members leading to an increase of 0.18 units in TCB adoption intensity. Further analysis showed that farm acreage (lnhect), was negative and significant at $p \leq 0.01$. The higher the farm size the lower the TCB technology intensification compared to large farm sizes. The variable farm fertility level (q2fert) was also negative and significant, at $\mathrm{p} \leq 0.05$. This implied that the lower the perceived fertility level, the lower the TCB intensification and vice versa.

The variable availability of TCB plantlets to farmers (q8tcavl) was positive and significant, $(\mathrm{p} \leq 0.05)$. The marginal analysis showed that a unit increase in the availability of TCB plantlets increases the level of TCB intensity of adoption by 0.71 units. The variable distance to banana market (lnq9dist2), was negative and significant, $(p \leq 0.10)$. The more the distances to the product market the less likelihood of TCB intensification. A unit increase in the distance to the markets leads to a 0.18 decrease in TCB intensity of TCB adoption.

The use of manure in planting banana (manuredm) was positive and significant at $\mathrm{p} \leq 0.01$ and a unit increase in manure use leads to a 1.98 increase in TCB intensification. In addition, contact with agricultural extension services (dismeext) was positive and significant at $p \leq 0.05$. A unit increase in the extension services leads to a unit increase in TCB intensity adoption. The variable average index of TCB technology attributes (aveindex) was negative and significant, $(\mathrm{p} \leq 0.05)$. The variable location of farmers in Bungoma County (bundumy) was positive and significant $(\mathrm{p} \leq 0.05)$. Every one unit of farm household in Bungoma County leads to 1.43 units increase level of TCB intensification.

\section{DISCUSSION}

The study aimed at determining factors that significantly influence the likelihood and extend of TCB technology adoption. The significant factors were classified into SE, TA, IF and EF factors.

\section{Socioeconomic factors (SE) \\ Information sources}

Despite the significant number of people being aware of the TCB, the adoption level was still low. Farmers' awareness of new technologies is an essential step toward their adoption. Farmers were aware of TCB technology through several information sources which included; research institutions, extension agents (both government and Non-Governmental Organization), radio programmes and fellow farmers (either neighbours or early adopters). Other common information sources include Field days and Agricultural Society of Kenya (ASK) shows. These information sources have been shown to be important dissemination pathways [34]. 


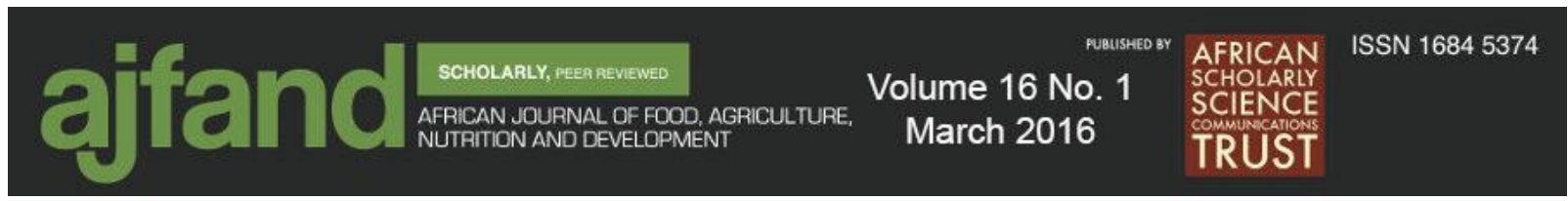

\section{Banana income}

Proportion of income received from banana (lnbanprop) significantly influenced adoption of TCB, implying that income from banana sales induced farmers to grow TCB. Thus, the higher the proportion of banana revenue at household level, the higher the adoption of TCB innovation. This could be attributed to the fact that farmers were interested in income generating farm enterprises in order to meet household financial obligations. Similar studies have shown positive effect of income both on and off-farm on technology adoption $[35,36]$. Therefore, any efforts to enhance household income either from farm and offfarm activities including credit would enhance technology adoption like TCB.

\section{Per capita expenditure}

Per capita household expenditure was positive and significant. This indicated that the higher the per capita household expenditure, the higher the likelihood of farmers adopting TCB technology. This could be attributed to the fact that income from TCB technology could be used in meeting household expenditure. Adoption of improved varieties had a significant positive impact on total households' expenditure [37]. This suggests that adoption of improved crop varieties like TCB innovation significantly generates an improvement in farming household living standards. Hence, efforts should be intensified to ensure farmers access adequate, quality and improved TCB plantlets at the right time. All programs, strategies and policies that could lead to increase in improved TCB adoption should be intensified in order to achieve the much desired poverty reduction and generate an improvement in rural farming households' welfare in western Kenya.

\section{Family size}

Family size household was positive and significant, implying that as the family size increases, the probability of adopting TCB also increases. This may also imply that banana producers in the study area primarily depended on family labour, with limited hired labourers for farm activities. This signifies low or lack of commercialization among farmers.

\section{Labour sources}

Intensity of agricultural technology use in farming can be influenced by amount and availability of labour on technology intensification [38]. The use of family members as the main labour source on the farm ( $\mathrm{q} 1 \mathrm{faml})$, was positive and significant $(\mathrm{p} \leq 0.01)$. The probability of TCB adoption increases by $17.7 \%$ for every member increase in the farming household situated in the study region. This implies that, as the family size of farming household increases, the intensity of adopting TCB increases. This may also imply that banana producers in the study area primarily depended on family labor in farming activities. Subsequently, labour use is crucial for enhanced investment in TCB intensification and subsequently commercialization. It has been shown that labour has a significant and positive effect on technology adoption [37]. 


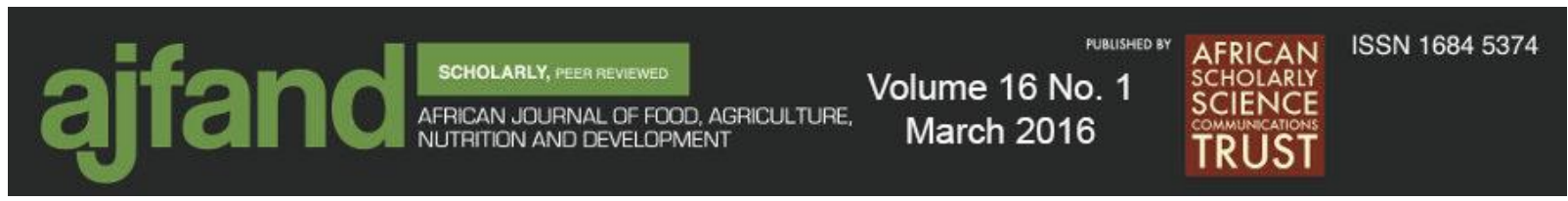

\section{Farm size}

The larger the farm size, the lower the TCB technology intensification. Farmers with smaller farm sizes were likely to intensify TCB technology which is a source food and surplus for sale to meet household financial obligations. This is in line with the project's and country's objectives of alleviating food insecurity among the smallholder farmers in the region as documented by other authors [5] and [39]. However, large scale farmers have also entered into the banana production using TCB.

\section{Off-farm employment}

This second stage model which explored level of TCB intensification among farmers revealed that a number of factors were significant. Off-farm employment of farmers was positive and significant $(\mathrm{p} \leq 0.01)$. One percentage increase in the availability of TCB would increase the adoption intensity of TCB by about $202.2 \%$. Probably this implies that those farmers who were engaged in off-farm occupation were likely to intensify TCB production by expanding banana acreage using the superior TCB plantlets for enhanced production. This is in line with the working hypothesis as these farmers are likely to have additional income which enhances their purchasing power to buy TCB plantlets. This result concurs with studies undertaken on banana adoption in Kenya and other similar environments that off-farm income has a significant effect on TCB adoption [40]. This is also in line with economic theory where more income means higher purchasing power for consumers and producers. Household head- members whose main occupation was farming implies that farmers who were engaged in farming as the main occupation, intensified TCB banana adoption. Given that banana production is increasingly being commercialized in Kenya, the productivity enhancing TCB technology is likely to be adopted by farmers who are inclined to farm for income generation.

\section{Technology attributes (TA) \\ TCB Technological attributes}

The index technology attributes was significant. According to Rogers' diffusion of Innovations theory (DIT), attributes in terms of relative advantage, compatibility, complexity, trialability, observability and possibly including the cost implication, may significantly influence on adoption $[41,43,44]$. The results showed that being a farmer in Bungoma County positively influenced TCB adoption meaning that being a farmer in Bungoma enhanced the TCB technology intensification. This could be attributed to low levels of banana acreage in the region against the competing crops like sugarcane.

\section{Accessibility to $\mathrm{TCB}$ plantlets}

Further analysis in the first and second hurdles showed accessibility of TCB plantlets to farmers was hypothesized to positively influence the likelihood and intensity of TCB adoption. The project was designed such that the planting material was to be availed to farmers either through formal or informal distribution systems [39, 45]. The variable availability of TCB plantlets to farmers (q8tcavl) was positive and significant, $(p \leq 0.05)$. One percentage point increase in the availability of TCB would increase the adoption of 


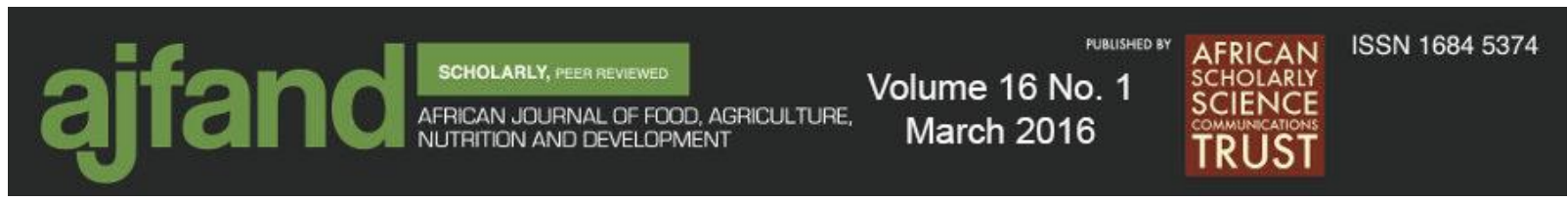

TCB by about $70.5 \%$. Enhanced access of farmers to TCB technology increased the intensification of TCB. This is in line with the priori working hypothesis that availability of TCB plantlets increases the intensity of adoption because the demand for TCB planting material is progressively increasing against the low supply. This implies that enhanced strategies to distribute plantlets to farmers will increase adoption of the technology.

\section{Institutional factors (IF) \\ Extension contact}

Farmers' contact with extension agents is expected to have a positive effect on adoption based on innovation-diffusion theory [16]. Therefore, such contacts expose farmers to availability of information that is expected to stimulate adoption; and a positive relationship is hypothesized between extension visits and the probability of adoption of a new technology. Contact with government extension agents enhanced the intensification of the TCB technology. This is true given that government extension agents are represented up to sub-location level. They also play a lead role in promoting the TCB technology in partnership with other agents along the banana value chain. Similar results of the positive impact of extension contact with farmers growing cowpea varieties have been reported by Adesina et al. [15]. However, it is recognized that despite the mobile telephony not being significant, it has been shown that perceived ease of its use, usefulness, relative advantage, compatibility and attitude, were found to be direct predictors of agricultural technology adoption behavior [46]. The study provides evidence for the potential of mobile technology in agriculture.

\section{Output market access}

Market accessibility is important in technology adoption through input acquisition and product sales. The longer the distance the more the transaction costs and the less the profit accrued by farmers. This could act as a disincentive in expanding the TCB technology. This demands the need to open up of more banana markets and value addition technologies including packaging to increase farmers' profit margins. Similar observations have been made by others and was attributed to high transaction costs [47, 48].

\section{Environmental factors (EF) \\ Geographical location of farmers}

Being a farmer in Kisii County positively and significantly influenced TCB technology uptake. This implies that farmers located in that county were more likely to participate in TCB technology production than those located in other areas. This is consistent with the fact that that this region (Kisii County) and its environs are favourable banana production zones and is also one of the main banana growing regions in Kenya with a relatively large number of small-scale farms compared to West Pokot, Bungoma and Trans Nzoia Counties. Farmers in Kisii region sell a lot of banana to other regions of Kenya, like Nairobi and Kisumu. Similar results have been reported by studies undertaken in Uganda on determinants of farm-level adoption of cultural practices for Banana Xanthomonas Wilt Control [49]. In addition, agro-ecological zone has been shown to influence the 


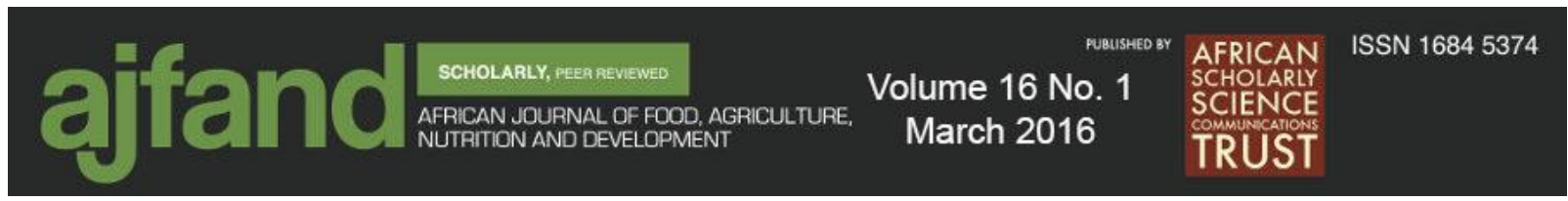

performance of banana varieties [50]. This trade orientation significantly contributes to farm revenue and probably the likelihood in TCB participation.

\section{Plot soil fertility levels}

The variable farm fertility level was negative and significant, implying that the lower the perceived fertility level, the higher the TCB intensification and vice versa. Since bananas generally require relatively high fertility levels, if the farms are relatively low in fertility levels, then expansion of TCB is likely to be high but probably with relatively enhanced use of manure. This could also be attributed to low yield of TCB technology under low fertility regimes. Reversing this trend requires optimal application of organic and inorganic fertilizers.

\section{Manure/mulch application}

Manure and mulch are considered the traditional techniques for maintaining banana plot productivity [51]. This implies that farmers who applied manure were likely to intensify TCB banana technology. This could be attributed to the fact that manure was available among the farmers and also not as expensive as inorganic fertilizers among farmers in the study region. The farmers were also aware that use of manure was part of the agronomic package of TCB technology for one to realize full benefits of the technology. It was observed that farmers apply manure in banana orchards, with a majority of them applying at least half of $20-\mathrm{kg}$ tin per stool [40]. The results also showed a significant effect of manure on banana production. This contributes to the enhanced use of manure among farmers who were expanding TCB technology.

\section{CONCLUSION}

Results of the study reveal the relative importance of each of the 21 variables discussed that may be considered to improve farmers' ability to adopt TCB technology. There were similarities and differences in the variables that were posited to significantly influence the probability of adoption and intensity of TCB technology. Those variables that significantly influenced probability of TCB adoption included: availability of TCB, banana revenue generated and the counties where the farmers were located. The major hurdles in the probability of adoption and intensity of TCB were: availability of TCB planting material, proportion of banana income to the total farm, per capita household expenditure and the location of the farmer in Kisii County compared to West Pokot. The variables that significantly influenced the TCB adoption intensity were: occupation of farmers, family size, labour source, farm acreage, farm fertility status, availability/access of TCB plantlets to farmers, distance to banana market, use of manure in planting bananas, agricultural extension services, average index technology attributes, and location of farmers in Kisii, Bungoma and Trans Nzoia counties, compared to West Pokot County. These factors are important in terms of targeting technologies as suggested by other similar studies. 


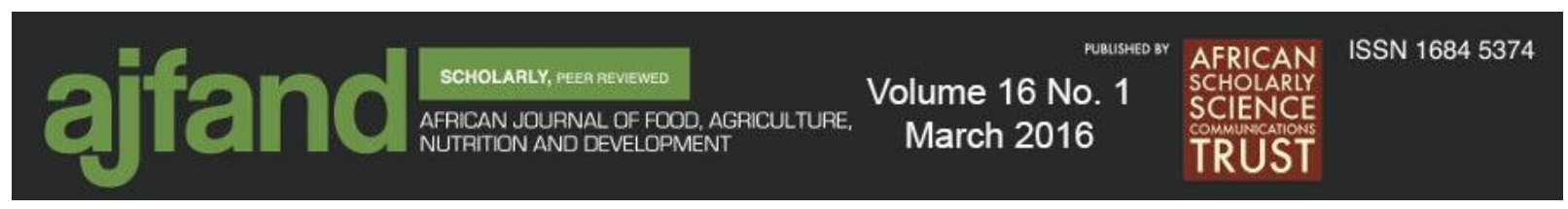

\section{RECOMMENDATIONS}

Based on these results, the technology developers and disseminators need to mitigate negative factors that impede TCB adoption and promote those ones that enhance adoption. Subsequently, the TCB disseminators need to utilize farm, farmer, environmental factors, technological attributes (traits), and environmental factors targeting interventions. This will fine-tune the targeting of TCB intervention strategies for enhanced adoption and impact. In addition, integration of both national county governments in up-scaling enhance TCB technology would enhance adoption probably by having TCB nurseries in each county. There is need to increase farmer extension contact probably by employing more extension personnel or utilizing extension strategies that enhance extension services to farmers through Information and Communication Technology (ICT). This can be done by using platforms of mobile service providers. In addition, training of farmers on TCB benefits and management of banana orchards might enhance likelihood and intensity of TCB adoption and reduce negative perceptions about the technology. Farmers also need to be sensitized on the importance of seeking extension services regularly for technical support and use productivity enhancing technological components like application of farm yard manure, pest/disease management.

\section{ACKNOWLEDGEMENTS}

The authors acknowledge financial support from the World Bank. We are indebted to the Director General KALRO, the Director Food Crops Research Institute - Kitale for facilitating and providing an enabling environment for conducting the research. We thank the farmers who gave their valuable time during the surveys. Finally, Annastacia Masinde, Pelengura and the late Okiyo are appreciated for fully assisting in data collection and management. We are responsible for any errors of omission and commission. 


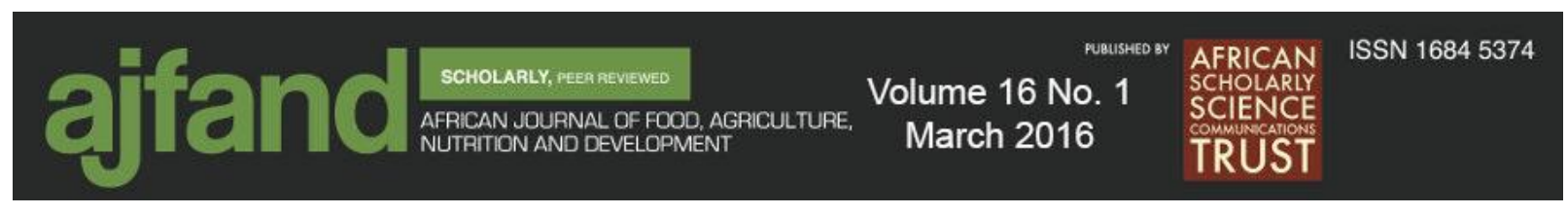

Table 1: Model variable definition and postulated effects

\begin{tabular}{|c|c|c|}
\hline Variable & Definition & $\begin{array}{c}\text { Exp. } \\
\text { sign }\end{array}$ \\
\hline Aveindex- $X_{1}$ & TCB technology attributes index & + \\
\hline bundumy- $X_{2}$ & Bungoma county dummy & + \\
\hline dismeext- $X_{3}$ & Access to government extension dummy & + \\
\hline dismefam- $X_{4}$ & Farmer-to-farmer extension dummy & + \\
\hline fertbdum- $X_{5}$ & Used inorganic fertilizer to plant dummy & + \\
\hline kisidumy- $X_{6}$ & Kisii county dummy & + \\
\hline lnbanprop- $X_{7}$ & Log of prop. banana revenue to total farm revenue $(\%)$ & + \\
\hline $\operatorname{lnhect-} X_{8}$ & Log of farm size area in ha. & + \\
\hline lnhhage $2-X_{9}$ & Log of age of head of household in year squared & + \\
\hline $\operatorname{lnpcdy}-X_{10}$ & Per capita consumption expenditure in KES & + \\
\hline $\operatorname{lnq} 10 \mathrm{bprca}-X_{11}$ & Price of banana plantlets-KES & + \\
\hline lnq1hhage- $X_{12}$ & age of head of household in year & + \\
\hline $\operatorname{lnq} 9$ dist $2-X_{13}$ & Distance to TCB plant source-km & - \\
\hline manuredm- $X_{14}$ & Used manure to plant dummy & + \\
\hline ocup_off- $X_{15}$ & Occupation of Household head -off-farm income-dummy & + \\
\hline ocup_far- $X_{16}$ & Occupation of HoH-farming dummy & + \\
\hline overinde- $X_{17}$ & Overall perception index of banana benefits & + \\
\hline q1faml- $X_{18}$ & Family size-number & + \\
\hline q1hheduc- $X_{19}$ & Head of household education level & + \\
\hline q1hhhmar- $X_{20}$ & Marital status of $\mathrm{HoH} 1=$ married; $0=$ otherwise & + \\
\hline q1hhsex- $X_{21}$ & Head of household sex $1=$ female & \pm \\
\hline $\mathrm{q} 2$ fert- $X_{22}$ & Fertility level of the farm & \pm \\
\hline q2labfam- $X_{23}$ & HH only uses family labour dummy & + \\
\hline q2labhr- $X_{24}$ & HH hired casual labour-dummy & + \\
\hline q33fdsht $-X_{25}$ & Food security-dummy & + \\
\hline q8tcavl- $X_{26}$ & Availability of TCB plantlets dummy & + \\
\hline trandumm- $X_{27}$ & Trans Nzoia county dummy & \pm \\
\hline kisidumy- $X_{28}$ & Kisii county dummy & \pm \\
\hline wpoktdymy- $X_{29}$ & West Pokot county dummy & \pm \\
\hline $\operatorname{lnq} 9$ dist2- $X_{30}$ & variable distance to banana market & - \\
\hline
\end{tabular}

Key: TCB - Tissue culture banana; KES - Kenya Shilling; HoH - Head of household; HH - Household. 


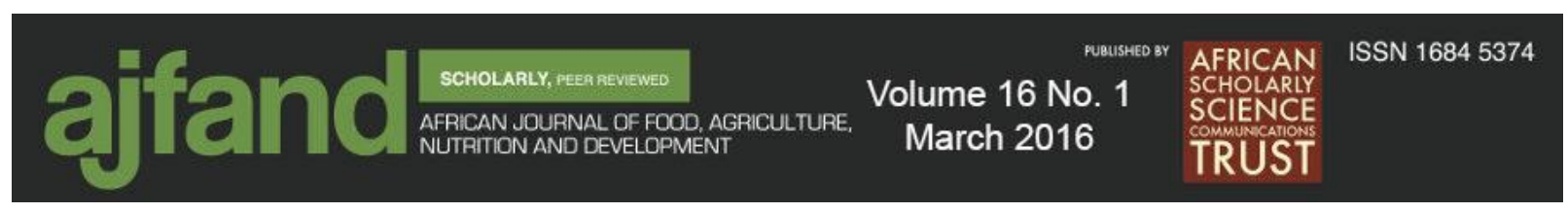

Table 2: Socio-economic variables' descriptive statistics

\begin{tabular}{|c|c|c|c|c|c|c|c|c|c|}
\hline & \multicolumn{2}{|c|}{$\begin{array}{l}\text { Full sample } \\
\qquad(\mathrm{n}=330)\end{array}$} & \multicolumn{2}{|c|}{$\begin{array}{l}\text { Adopters } \\
\qquad(n-65)\end{array}$} & \multicolumn{2}{|c|}{$\begin{array}{r}\text { Non- } \\
\text { participating } \\
(\mathrm{n}=149)\end{array}$} & \multicolumn{2}{|c|}{ Statistic } \\
\hline & & Mean & SD & Mean & SD & Mean & SD & t-value & $\begin{array}{l}\text { Chi- } \\
\text { square }\end{array}$ \\
\hline \multicolumn{2}{|l|}{ Family size } & 7.0 & 2.6 & 6.9 & 2.4 & 7.2 & 2.8 & 1.12 & $\ldots$ \\
\hline \multicolumn{2}{|c|}{ Age of HoH-years } & 51.4 & 13.3 & 51.2 & 13.3 & 51.6 & 13.4 & 0.67 & $\ldots$ \\
\hline \multirow{2}{*}{\multicolumn{2}{|c|}{$\begin{array}{l}\text { Distance source }-\mathrm{km} \\
\text { Period planted bananas-years }\end{array}$}} & 37.1 & 9.17 & 38.3 & 9.8 & 14.3 & 20 & $4.88 * * *$ & $\ldots$ \\
\hline & & 23.0 & 13.85 & 17.5 & 14.3 & 13.8 & 12.4 & 0.253 & $\ldots$ \\
\hline \multicolumn{2}{|c|}{ Period planted TCB-years } & & & 6.5 & 5.2 & & & & $\ldots$ \\
\hline \multicolumn{2}{|c|}{ Period in farming-years } & 20.9 & 13.3 & 20.3 & 14 & 21.6 & 12.3 & 0.58 & $\ldots$ \\
\hline \multicolumn{2}{|c|}{ Livestock ownership (TLU) } & 6.1 & 12.2 & 7.5 & 16 & 4.4 & 3.9 & & $\ldots$ \\
\hline \multicolumn{2}{|c|}{ Farm size in ha } & 8.8 & 55.3 & 10.7 & 65.5 & 6.7 & 40.8 & 0.67 & $\ldots$ \\
\hline \multicolumn{2}{|c|}{ Arable area in ha. } & 7.1 & 4.6 & 8.7 & 59 & 5.3 & 3.6 & 0.66 & $\ldots$ \\
\hline \multicolumn{2}{|c|}{ Number of banana stools } & 84.1 & 34.1 & 126.7 & 45.5 & 35.5 & 52 & $2.25 * *$ & $\ldots$ \\
\hline \multicolumn{2}{|c|}{ Number of TCB banana stools } & 54.0 & 37.8 & 131.3 & 58.9 & ... & $\ldots$ & & $\ldots$ \\
\hline \multirow{2}{*}{\multicolumn{2}{|c|}{$\begin{array}{l}\text { TCB performance index } \\
\text { Proportion Banana revenue- } \\
\text { farm }\end{array}$}} & 24.1 & 16.4 & 26.9 & 18.2 & 20.8 & 13.3 & $5.02 * * *$ & $\ldots$ \\
\hline & & 49.3 & 42.8 & 54.4 & 41.7 & 43.0 & 39.53 & $2.20 * *$ & $\ldots$ \\
\hline \multirow{3}{*}{$\begin{array}{l}\text { Main } \\
\text { occupation } \\
\mathrm{HoH} \%\end{array}$} & Farming & & 73.1 & & 73.6 & & 72.7 & $\ldots$ & 0.85 \\
\hline & Petty trade & & 8.6 & & 5.2 & & 12.7 & $\ldots$ & $5.14 * *$ \\
\hline & Off- farm & & 1.5 & & 17.2 & & 12.7 & $\ldots$ & 0.51 \\
\hline \multirow{2}{*}{$\begin{array}{l}\text { Gender of } \\
\mathrm{HoH} \%\end{array}$} & Male & & 8.5 & & 45.2 & & 37.2 & $\ldots$ & 1.4 \\
\hline & Female & & 7.5 & & 16 & & 19.3 & $\ldots$ & 1.5 \\
\hline \multirow{4}{*}{$\begin{array}{l}\text { Education } \\
\mathrm{HoH} \%\end{array}$} & None & & 4.9 & & 3.4 & & 6.7 & $\ldots$ & $2.691 * * *$ \\
\hline & Primary & & 47.4 & & 44.6 & & 50.7 & $\ldots$ & 0.77 \\
\hline & Secondary & & 28.6 & & 26.9 & & 30.7 & $\ldots$ & $61.1 * * *$ \\
\hline & Post-secondary & & 19.1 & & 25.1 & & 12 & $\ldots$ & $128.6 * * *$ \\
\hline \multirow{5}{*}{$\begin{array}{l}\text { Land } \\
\text { tenure \% } \\
\text { Soil } \\
\text { fertility \% }\end{array}$} & $1=$ with title & & 56.1 & & 52.1 & & 61.3 & $\ldots$ & 1.6 \\
\hline & $0=$ without & & 37.1 & & 47.9 & & 38.7 & $\ldots$ & 1.6 \\
\hline & low dummy & & 9.0 & & 10.4 & & 7.3 & $\ldots$ & $223.2 * * *$ \\
\hline & medium dummy & & 68.7 & & 67.6 & & 70 & $\ldots$ & $46.0 * * *$ \\
\hline & High dummy & & 22.3 & & 22 & & 27.7 & $\ldots$ & $101.8 * * *$ \\
\hline \multirow{2}{*}{$\begin{array}{l}\text { Labour } \\
\text { source } \%\end{array}$} & Family & & 83.7 & & 83.9 & & 83.5 & $\ldots$ & 0.2 \\
\hline & Hired & & 73.8 & & 78.6 & & 65.5 & $\ldots$ & $2.11 * *$ \\
\hline
\end{tabular}

Key: ... implies not applicable; TCB - Tissue culture banana; HoH - Head of household Source: Survey data 2011/12 


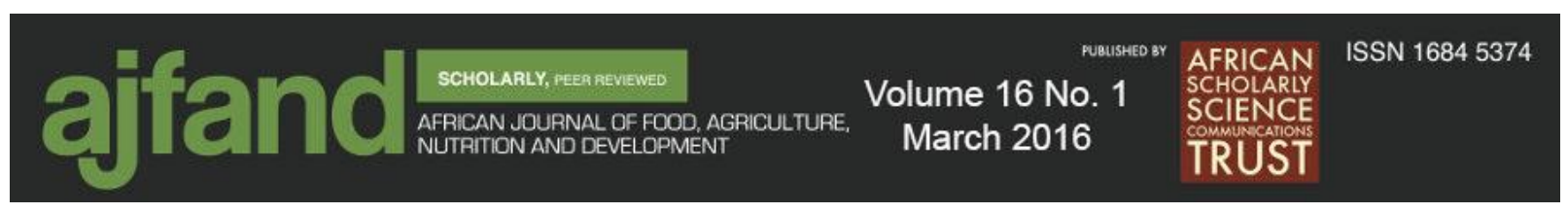

Table 3: Parameter estimates of the generalized double hurdle model of TCB adoption in Kenya

\begin{tabular}{|c|c|c|c|c|c|c|}
\hline \multirow[t]{2}{*}{ Variable } & \multicolumn{3}{|c|}{ First Tier } & \multicolumn{3}{|c|}{ Second Tier } \\
\hline & Coef & $\mathrm{ME}$ & $\mathrm{SE}$ & Coef & $\mathrm{ME}$ & SE \\
\hline lnq10bprc_a & -0.039 & -0.004 & 0.0094 & 0.035 & 0.0341 & 0.0850 \\
\hline lnq1hhage & $\ldots$ & $\ldots$ & $\ldots$ & -0.190 & -0.187 & 0.691 \\
\hline Lnhhage2 & 0.180 & 0.012 & 0.037 & $\ldots$ & $\cdots$ & $\ldots$ \\
\hline q1hhsex & 0.580 & 0.056 & 0.045 & $\ldots$ & $\ldots$ & $\ldots$ \\
\hline q1hheduc & 0.343 & 0.038 & 0.024 & $\ldots$ & $\ldots$ & $\ldots$ \\
\hline occ_off & 0.064 & 0.007 & 0.056 & $2.235 * * *$ & 2.022 & 0.552 \\
\hline Ocup_far & .. & $\ldots$ & $\ldots$ & $1.625 * * *$ & 1.577 & 0.613 \\
\hline q1hhhmar & -0.244 & -0.029 & 0.068 & 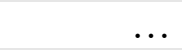 & $\ldots$ & \\
\hline q1faml & -0.108 & -0.012 & 0.008 & $0.180 * * *$ & 0.177 & 0.067 \\
\hline Lnhect & -0.030 & -0.003 & 0.016 & $-0.314 * * *$ & -0.309 & 0.113 \\
\hline q8tcavl & $2.015 * * *$ & 0.336 & 0.088 & $0.717 * * *$ & 0.705 & 0.311 \\
\hline $\operatorname{lnq} 9$ dist2 & & .. & $\ldots$ & $-0.183 * * *$ & -0.180 & 0.097 \\
\hline q2labfam & -0.602 & -0.078 & 0.096 & -0.087 & -0.085 & 0.378 \\
\hline Manuredm & 0.930 & 0.079 & 0.042 & $2.141 * * *$ & 1.984 & 0.634 \\
\hline Fertbdum & 0.349 & 0.042 & 0.072 & 0.651 & 0.635 & 0.569 \\
\hline q33fdsht & -0.139 & -0.016 & 0.04 & $\cdots$ & .. & $\cdots$ \\
\hline Lnbanprop & $0.159 * *$ & 0.018 & 0.009 & 0.017 & 0.017 & 0.092 \\
\hline Lnpcdy & $0.197^{*}$ & 0.022 & 0.012 & & & \\
\hline Dismeext & 0.065 & 0.007 & 0.037 & $1.018 * * *$ & 0.997 & 0.316 \\
\hline Dismefam & .. & $\ldots$ & ... & 0.783 & 0.761 & 0.497 \\
\hline Aveindex & $\ldots$ & $\ldots$ & $\ldots$ & $-0.016 * *$ & -0.016 & 0.008 \\
\hline Overinde & $\ldots$ & $\ldots$ & $\cdots$ & 0.004 & 0.004 & 0.018 \\
\hline Trandumm & 0.411 & 0.046 & 0.047 & 0.248 & 0.244 & 0.437 \\
\hline Bundumy & 0.111 & 0.013 & 0.081 & $1.534 * *$ & 1.435 & 0.649 \\
\hline Kisidumy & $1.862 *$ & 0.132 & 0.044 & -1.047 & -1.021 & 1.565 \\
\hline Cons & -5.003 & & & 0.045 & & \\
\hline Sigma & & & & 1.066 & & \\
\hline Number of obs & & & & 66 & & \\
\hline Prob > chi2 & & & & 0.000 & & \\
\hline Truncated regres & & & & & & \\
\hline Wald chi2 & & & & 67.800 & & \\
\hline Log likelihood & & & & 95.244 & & \\
\hline No. of iterations & & & & 5 & & \\
\hline
\end{tabular}

Notes: Coef. means Coefficient; SE is standard error; and ME is the marginal effect $* * * \mathrm{p} \leq 0.01$; and $* * \mathrm{p} \leq 0.05$ denote significance at the $1 \%$, and $5 \%$ levels, respectively Source: Survey data 2012 


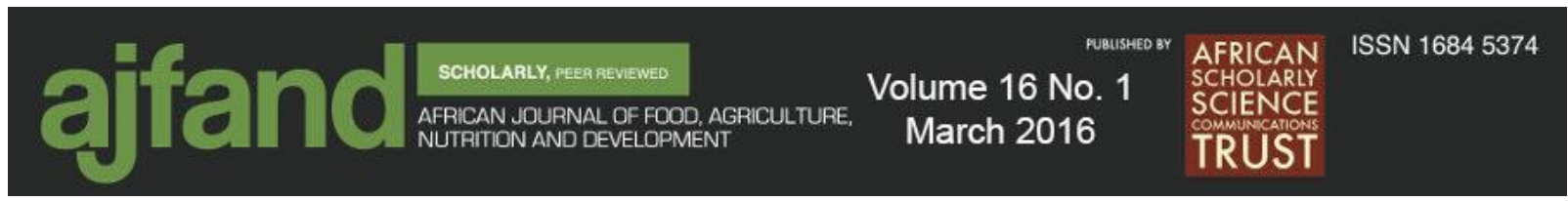

\section{REFERENCES}

1. GoK. Strategy for revitalizing agriculture 2004-20014. . In Nairobi, Kenya. Ministries of Agriculture, Livestock and Fisheries Development, and Cooperative Development and Marketing. 2004.

2. GoK. Kenya Vision 2030. The Popular Version. In Nairobi, Kenya, Government Ministry. 2007:1-32.

3. McIntyre BD, Herren HR and J Wakhungu Watson RT. Agriculture at a Crossroads. Sub-Saharan Africa (SSA) Report. In Beverly D. McIntyre HRH, Judi Wakhungu, Robert T. Watson (ED). Volume V, Island Press, International Assessment of Agricultural Knowledge, Science and Technology for Development. 2009:1-606.

4. FAO. Planning for Sustainable Use of Land Resources. Towards New Approach. Rome, Italy. 1995:1-60.

5. Wambugu F Food, Nutrition and Economic Empowerment: The Case for Scaling up the Tissue Culture Banana Project to the Rest of Africa. Paper Presented at the NEPAD/IGAD Regional Conference in November 22-25, 2004. Agricultural Successes in the Greater Horn of Africa. NEPAD/IGAD. Nairobi, Kenya. 2004: 18.

6. Nyang MN, Webo C and RL Roothaert The Power of Farmers Organisations in Smallholder Agriculture in East Africa Working Papers. A review of 5 project initiatives of the Maendeleo Agricultural Technology Fund. In FARM-Africa Working Paper, London, UK, FARM-Africa. 2010: 1-44.

7. Feder GR, Just RE and D Zilberman Adoption of Agricultural Innovations in Developing Countries: A survey. Economic Development and Cultural Change. 1985; 33(2): 255-295.

8. Beshir B and D Wegary Determinants of Smallholder Farmers' Hybrid Maize Adoption in the Drought Prone Central Rift Valley of Ethiopia. African Journal of Agricultural Research. 2014; 9(17): 1334-1343.

9. Nowak PJ and PJ Korsching Social and Institutional Factors Affecting the Adoption and Maintenance of Agricultural BMPs. In: Schaller, F. \& Bauley, H. Agricultural Management and Water Quality, 1st ed. Ames, Iowa: Iowa University Press. 1983: 349-373.

10. Rogers EM Diffusion of Innovations. New York, Free Press. 2003: 1-477. 


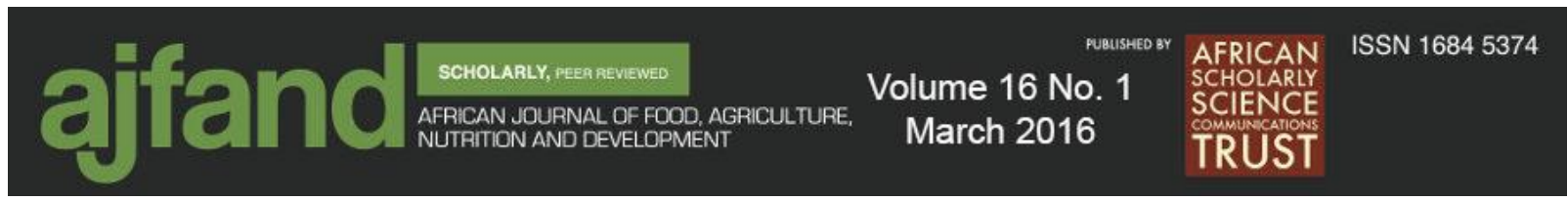

11. Doss CR Analyzing Technology Adoption Using Microstudies: Limitations, Challenges, and Opportunities for Improvement. Agricultural Economics. 2006; 34: 207-219.

12. Baidu-Forson J Factors Influencing Adoption of Land-Enhancing Technology in the Sahel: Lessons from a Case Study in Niger. Agricultural Economics. 1999; 20:231-239.

13. Feder $\mathbf{G}$ and $\mathbf{R}$ Slade The Acquisition of Information and the Adoption of New Technology. American Journal of Agricultural Economics. 1984; 66: 312-320.

14. Adesina AA and J Baidu-Forson Farmers' Perception and Adoption of New Agricultural Technology: Evidence from Analysis in Burkina Faso and Guinea, West Africa. Agricultural economics. 1995; 13: 1-9.

15. Adesina AA and MM Zinnah Technology Characteristics, Farmers' Perceptions and Adoption Decisions: A Tobit Model Application in Sierra Leone Agricultural Economics 1993;9: 297-311.

16. Sani A, Abubakar BZ, Yakubu DH, Atala TK and L Abubakar SocioEconomic Factors Influencing Adoption of Dual-Purpose Cowpea Production Technologies in Bichi Local Government Area of Kano State, Nigeria. Asian Journal of Agricultural Extension, Economics and Sociology 2014; 3(4): 258-279.

17. RoK. Trans Nzoia County Development Profile Towards A Globally Competitive and Prosperous Kenya. Ministry of Devolution and Planning. 2013.

18. Jaetzold R, Schmidt H, Hornetz B and C Shisanya Farm Management Handbook of Kenya - Natural Conditions and Farm Management Information - VOL. II. West Kenya-Subpart A1. Western Province. Government printers. Nairobi, Kenya. 2005:319.

19. RoK. Bungoma County Development Profile Towards A Globally Competitive and Prosperous Kenya. Ministry Of Devolution and Planning May 2013.

20. RoK. Results of 1999 Population and Housing Census. In Nairobi, Kenya. Ministry of Finance and Planning, 1999.

21. RoK. West Pokot County Development Profile Towards A Globally Competitive and Prosperous Kenya. Ministry Of Devolution and Planning May 2013.

22. RoK. Kisii County Development Profile Towards A Globally Competitive and Prosperous Kenya. Ministry of Devolution and Planning May 2013.

23. Wooldridge JM Econometric Analysis of Cross Section and Panel Data. The MIT Press, Cambridge, Massachusetts London, England. 2002. 


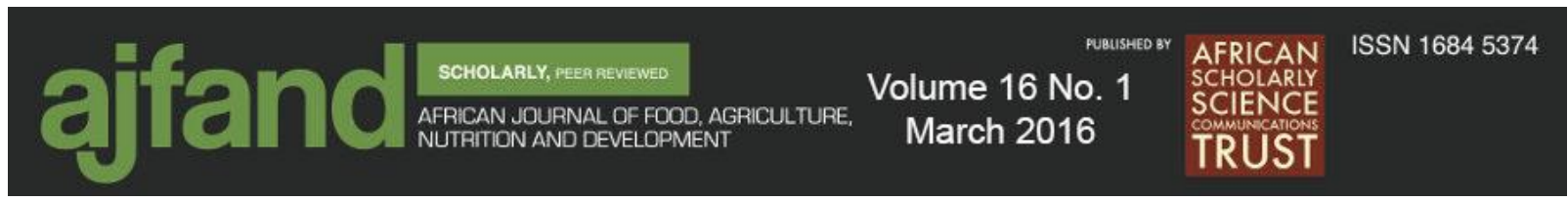

24. Akinbode SO and AO Dipeolu Double-Hurdle Model of Fresh Fish Consumption among Urban Households in South-West Nigeria. Current Research Journal of Social Sciences. 2012; 4(6): 431-439.

25. Yimer $\mathbf{S}$ Determinants of food consumption expenditure in Ethiopia Int. J. Eco. Res. 2011; 2(5): 151-165.

26. Morris ML, Tripp R and AA Dankyi Adoption and Impacts of Improved Maize Production Technology: A Case Study of the Ghana Grains Development Project. Economics Program Paper 99-01. Mexico, D.F.: CIMMYT. 1999.

27. Doss CR Understanding Farm Level Technology Adoption: Lessons Learned from CIMMYT's Micro Surveys in Eastern Africa. CIMMYT Economics Working Paper 03-07. Mexico, D.F: CIMMYT. 2003.

28. Xu Z, Burkea WJ, Jayne TS and J Govereh Do input subsidy programs "crowd in" or "crowd out" commercial market development? Modeling fertilizer demand in a two-channel marketing system. Agricultural Economics. 2009; 40 : 79-94.

29. Rao EJO and M Qaim The supermarket revolution and impacts on agricultural labor markets: Empirical evidence from Kenya. In RTG 1666 GlobalFood Heinrich Düker Weg 1237073 Göttingen Germany. 2011: 1-29. www.unigoettingen.de/globalfood. Accessed October 2013.

30. Blundell RW and CA Meghir Bivariate Alternatives to the Univariate Tobit Model. Journal of Econometrics. 1987; 33 (January/February): 179-200.

31. Moffat PG Hurdle models of loan default. Journal of the Operational Research Society. 2005; 56(9): 1063-1071.

32. Greene GH Limited dependent variables - truncation, Censoring, and sample selection, Chapter 19. 2010: 833-902.

33. Burke WJ Fitting and Interpreting Cragg's Tobit Alternative Using Stata. The Stata Journal. 2009; 9 (4): 584-592.

34. Murage AW, Amudavi DM, Obare G, Chianu J, Midega CAO, Pickett JA and ZR Khan Determining Smallholder Farmers' Preferences for Technology Dissemination Pathways: The case of "Push-Pull" Technology in the Control of Stemborer and Striga in Kenya. International Journal of Pest Management. 2011; 57(2): 133 - 145. 


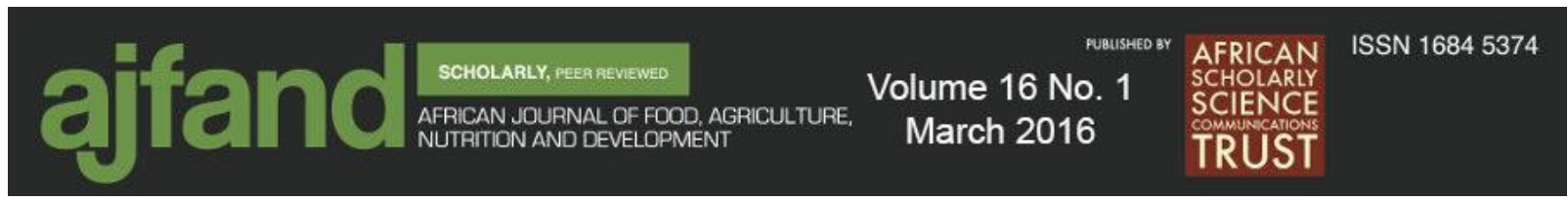

35. Abdoulaye T, Abass A, Maziya-Dixon B., Tarawali G, Okechukwu R, Rusike J, Alene A, Manyong V and B Ayedun Awareness and Adoption of Improved Cassava Varieties and Processing Technologies in Nigeria. Journal of Development and Agricultural Economics. 2014; 6(2): 67-75.

36. Pandit M, Paudel KP and KK Paudel Effect of Remittance on Intensity of Agricultural Technology Adoption in Nepal. Selected Paper Prepared for Presentation at the Southern Agricultural Economics Association 2014 Annual Meeting, Dallas, Texas, February 1-4, 2014.

37. Awotide BA, Diagne A, Awoyemi TT and VET Ojehomon Impact of Seed Voucher System on Rice Yield, Income Inequality and Poverty Reduction in Rural Nigeria: A Randomized Control Trial Approach. A Contributed Paper Prepared for Presentation at The 26th International Conference of the Centre for the Studies of African Economies (CSAE), St. Catherine's College Oxford, U.K. 18-20 March, 2012. 2012: 1-33.

38. Beshir $\mathbf{H}$ Factors Affecting the Adoption and Intensity of Use of Improved Forages in North East Highlands of Ethiopia. American Journal of Experimental Agriculture. 2014; 4(1): 12-27.

39. Mbogoh SG, Wambugu FM and S Wakhusama Socio-Economic Impact of Biotechnology Applications: Some Lessons from the Pilot Tissue Culture (TC) Banana Production Promotion Project in Kenya, 1997-2002. Document Transformation Technologies. Proceedings of the 25th International Conference of Agricultural Economists (IAAE). Durban, South Africa, 16 - 22 August 2003. 2003.

40. Langat BK, Ngéno VK, Nyangweso PM, Mutwol MJ, Kipsat MJ, Gohole L and S Yaninek Drivers of Technology Adoption in a Subsistence Economy: The case of Tissue Culture Bananas in Western Kenya. Invited Paper Presented at The 4th International Conference of the African Association of Agricultural Economists, September 22-25, 2013, Hammamet, Tunisia. 2013: 1-17.

41. Couros A and $\mathbf{C}$ Kesten Innovation, Change Theory and the Acceptance of New Technologies: A Literature Review. 2003: 1-42.

42. Rogers EM Diffusion of Innovations (4th ed.). New York: The Free Press. 1995.

43. Komolafe SE, Adesiji GB and BO Ajibola Determinants of adoption of improved crop practices among women farmers in Ekiti East Local Government Area of Ekiti State, Nigeria. Journal of Agricultural Research. 2014; 2(7): 98-105. 


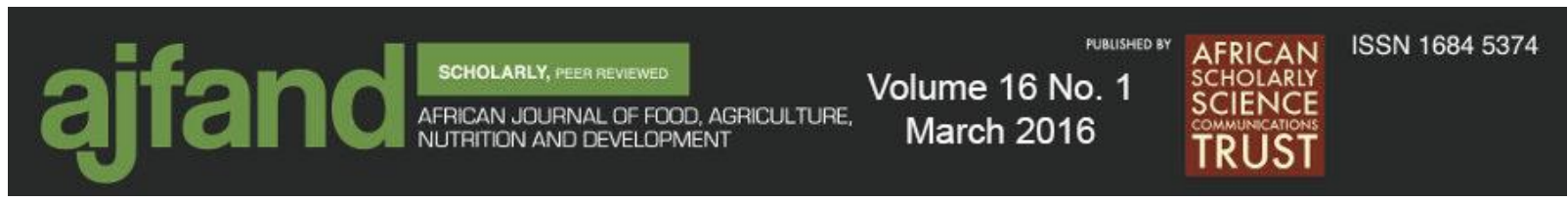

44. Kalinda T, Tembo G and E Kuntashula Adoption of Improved Maize Seed Varieties in Southern Zambia. Asian Journal of Agricultural Sciences. 2014; 6(1): 33-39.

45. Njuguna MM, Wambugu FM, Acharya SS and MA Mackey Socio-Economic Impact of Tissue Culture Banana (Musa spp.) in Kenya through the Whole Value Chain Approach. Acta Hort. 879. In Acta Hort. 879, ISHS Nairobi, Kenya, 2010.

46. Okuboyejo SR and AO Adejo Adoption of Mobile Technology by Farmers in Southwest-Nigeria: A Cross-Sectional Study. International Journal of ICT Research and Development in Africa archive. 2012; 3 (2): 32-44.

47. Adeoti AI, Oluwatayo IB and RO Soliu Determinants of Market Participation among Maize Producers in Oyo State, Nigeria. British Journal of Economics, Management and Trade. 2014; 4 (7): 1115-1127.

48. Martey E, Wiredu AN, Etwire PM, Fosu M, Buah SSJ, Bidzakin J, Ahiabor BDK and F Kusi Fertilizer Adoption and Use Intensity among Smallholder Farmers in Northern Ghana: A Case Study of the AGRA Soil Health Project Interactive Services Detection. Sustainable Agriculture Research. 2014; 3(1): 2136.

49. Jogo W, Karamura E, Tinzaara W, Kubiriba J and A Rietveld Determinants of Farm-Level Adoption of Cultural Practices for Banana Xanthomonas Wilt Control in Uganda. Journal of Agricultural Science 2013;5(7): 70-81.

50. Kamira M, Crichton RJ, Kanyaruguru J-P, van Asten PJA, Blomme G, Lorenzen J, Njukwe E, Van den Bergh I, Ouma E and P Muchunguzi Agronomic Evaluation of Common and Improved Dessert Banana Cultivars at Different Altitudes across Burundi. In Blomme, G., P. van Asten, and B. Vanlauwe. 2014 (eds.). Banana Systems in the Humid Highlands of Sub-Saharan Africa Enhancing Resilience and Productivity. 2013: 37-48.

51. Mpiira S, Staver C, Kagezi GH, Wesiga J, Nakyeyune C, Ssebulime G, Kabirizi J, Nowakunda K, Karamura E and WK Tushemereirwe The Use of Trees and Shrubs to Improve Banana Productivity and Production in Central Uganda: An Analysis of the Current Situation In Blomme, G., P. van Asten, and B. Vanlauwe. 2014 (eds.). Banana Systems in the Humid Highlands of Sub-Saharan Africa Enhancing resilience and Productivity. International Institute of Tropical Agriculture (IITA), Kampala, Uganda. 2013. 